\title{
Inoculação e sobrevivência de Xanthomonas vesicatoria em sementes de tomateiro
}

\author{
Fábio Mathias Corrêa ${ }^{1 *}$; Aldir de Oliveira de Carvalho ${ }^{1 ;}$ Margarida Goréte Ferreira do Carmo ${ }^{1 * *}$
}

${ }^{1}$ Departamento de Fitotecnia, IA, Universidade Federal Rural do Rio de Janeiro, CEP.: 23.890-000, Seropédica, RJ, e-mail: gorete@ufrrj.br; *Bolsista de Iniciação Científica CNPq/PIBIC; ${ }^{* *}$ Bolsista do CNPq.

Data de chegada:27/10/2005. Aceito para publicação em:11/05/2007

\section{RESUMO}

Corrêa, F.M.; Carvalho, A.O.; Carmo, M.G.F. Inoculação e sobrevivência de Xanthomonas vesicatoria em sementes de tomateiro. Summa Phytopathologica, v.34, n.1, p.71-75, 2008

Para avaliar o efeito de métodos de inocuação de Xanthomonas vesicatoria (Doidge) (9) em sementes de tomate sobre a qualidade da semente e transmissão da fitobactéria compararam-se os tratamentos: 1) inoculação a vácuo com suspensão de células de $X$. vesicatoria em STP $(0,005 \mathrm{M}, \mathrm{pH} 7,4$ e $\mathrm{NaCl} 0,85 \%) ; 2$ ) imersão por 24 horas em suspensão de células de $X$. vesicatoria em STP; 3) vácuo em solução STP; 4) imersão por 24 horas em STP; 5) imersão por $5 \mathrm{~min}$. em álcool etílico e 6) semente original. As avaliações foram realizadas por testes de germinação e isolamentos em meio Nutriente Agar Modificado
(NAM) aos 1, 15, 30 e 45 dias após aplicação dos tratamentos. Em seguida, avaliou-se o efeito da umidade (4\% e $8 \%$ ) e o armazenamento das sementes inoculadas e variações de umidade antes da realização dos testes sobre a sobrevivência e recuperação de $X$. vesicatoria. Os métodos de inoculação testados podem ser utilizados em trabalhos de rotina, porém, as sementes devem ser utilizadas até 30 dias após a inoculação a partir de quando ocorre uma redução acentuada na taxa de recuperação da fitobactéria. A umidade das sementes interfere na sobrevivência e na transmissão de $X$. vesicatoria pelas sementes de tomate.

Palavras chave: Lycopersicon esculentum; patologia de sementes; flora microbiana.

\section{ABSTRACT}

Corrêa, F.M.; Carvalho, A.O.; Carmo, M.G.F. Inoculation and survival of Xanthomonas vesicatoria on tomato seeds. Summa Phytopathologica, v.34, n.1, p.71-75, 2008

The efficiency of six methods of Xanthomonas vesicatoria (Doidge) (9) inoculation on tomato seeds, and their effects on seed quality were tested : 1) vacuum inoculation with $X$. vesicatoria cell suspension in $\mathrm{PB}(0.005 \mathrm{M}, \mathrm{pH} 7.4 \mathrm{e} \mathrm{NaCl} 0.85 \%)$; 2) immersion for 24 hours in with $X$. vesicatoria cell suspension and $\mathrm{PB} .3$ ) vacuum and saline solution in phosphate buffer; 4) immersion in PB for 24 hours; 5) seeds + ethanol; 6) control. Evaluations were performed for germination test and isolation in Modified Agar Nutrient (NAM)) at $1,15,30$ and 45 days after treatments imposition. The moisture effect on the transmission of $X$. vesicatoria seeds inoculated under vacuum, followed or not by air drying at $30 \pm 1{ }^{\circ} \mathrm{C}$, until $4 \%$ and $8 \%$ moisture were tested. Evaluations were performed as described above, after 24 hours and 30 days after the treatments. The methods of $X$. vesicatoria inoculation in tomato seeds can be used on routine analyses, however, inoculated seeds should be used until 30 days after inoculation. After this period, a large reduction on the recovery of viable cells occurs. The seed water content interferes with $X$. vesicatoria survival and transmission and explains the low percentages of $X$. vesicatoria recovery.

Additional keywords: Lycopersicon esculentum; seed pathology, microbial flora;

Sementes de tomateiro (Lycopersicon esculentum Mill) infectadas por Xanthomonas vesicatoria (Doidge) (9), representam uma das principais fontes de inóculo primário para a ocorrência de epidemias da mancha bacteriana. Para estudos de métodos de detecção, de tratamentos e de mecanismos de transmissão é necessário dispor-se de amostras de sementes homogêneas quanto à sua qualidade fisiológica e sanitária que podem ser obtidas por meio de inoculações programadas que resultem no mínimo de danos às sementes (4). Existem diferentes métodos de inoculação de sementes com fitobactérias $(1,6)$, porém não existem relatos de comparações entre os mesmos quanto à sua eficiência, aos danos causados às sementes e à sobrevivência do patógeno nas sementes armazenadas. $\mathrm{O}$ presente trabalho foi realizado com o objetivo de avaliar a eficiência de métodos de inoculação de sementes de tomate $\operatorname{com} X$. vesicatoria e a sobrevivência da fitobactéria nas sementes armazenadas.

Os experimentos foram realizados no Laboratório de Epidemiologia e Patologia de Sementes do Departamento de Fitotecnia da UFRuralRJ. Foram utilizadas sementes da cultivar Santa Clara Miss Brasil, e suspensão de células do isolado ENA 4463 de X. vesicatoria, preservado em água e crescido em meio Nutriente Agar (3) por 48 horas a $28^{\circ} \mathrm{C}$. As suspensões foram preparadas em solução tampão fosfato - STP $(0,005 \mathrm{M}, \mathrm{pH} 7,4$ e $\mathrm{NaCl} 0,85 \%)$ e a concentração ajustada para $10^{8} \mathrm{ufc} \mathrm{ml}{ }^{-1}$ com auxílio de espectrofotômetro ( $85 \%$ de transmitância a $540 \mathrm{~nm}$ ).

Compararam-se seis tratamentos, incluindo procedimentos usados na inoculação das sementes e testemunhas: 1) inoculação a vácuo com suspensão de células de $X$. vesicatoria em STP $(0,005 \mathrm{M}, \mathrm{pH} 7,4$ e $\mathrm{NaCl} 0,85 \%$ );2) imersão por 24 horas em suspensão de células de $X$. vesicatoria em STP; 3) vácuo em solução STP; 4) imersão por 24 horas em STP; 5) imersão por 5 min. em álcool etílico e 6) semente original. Para cada tratamento foram utilizadas 10.000 sementes. As sementes de todos os tratamentos, exceto o último, foram previamente 
imersas em álcool $\left(92^{\circ}\right.$ G.L. a 95\%) por 5 min. Em seguida, foram peneiradas e distribuídas sobre papel germitest e expostas em câmara de fluxo laminar até evaporação completa do álcool. Na inoculação a vácuo, as sementes foram imersas em $120 \mathrm{ml}$ da suspensão bacteriana, contida em erlenmeyers, e após $30 \mathrm{~min}$. de repouso em geladeira, foram submetidas a vácuo de $680 \mathrm{mmHg}$ durante $5 \mathrm{~min}$, seguidos de liberação lenta, em dois ciclos sucessivos $(1,8)$. Após o término do processo, as sementes foram mantidas em fluxo laminar durante $12 \mathrm{hs}$ para eliminar o excesso de umidade. Em seguidas as sementes foram armazenadas em ambiente refrigerado, à temperatura aproximada de 5 ${ }^{\circ} \mathrm{C}$, até a realização dos testes. Para o método de inoculação por imersão, as sementes foram imersas na suspensão de células bacterianas e levadas à geladeira por $24 \mathrm{hs}$, quando foram retiradas, distribuídas sobre papel germitest e secas em câmara de fluxo laminar por 12 hs. Em seguida, foram acondicionadas em frascos de plástico e conservadas em geladeira, até a realização dos testes. Antes de se avaliar o efeito dos diferentes tratamentos sobre a qualidade fisiológica e sanitária das sementes, avaliou-se o teor de umidade das mesmas (2).

As avaliações foram realizadas ao 1, 15, 30 e 45 dias da aplicação dos tratamentos de inoculação através de isolamentos em meio Nutriente Agar Modificado - NAM (6) e de germinação (2). Para isolamento, utilizaram 400 sementes que foram depositadas diretamente sobre o meio de cultura, seguido de incubação por $72 \mathrm{hs} \mathrm{a}$ $28^{\circ} \mathrm{C}$. Para o teste de sanidade em gerbox, as sementes foram semeadas sobre papel germitest, umedecido ( $2,5 \mathrm{x}$ o peso do papel) e mantidas em câmara BOD por 10 dias sob temperatura média de $25^{\circ} \mathrm{C}$ e 12 horas de fotoperíodo (8). Utilizou-se o delineamento de blocos ao acaso com quatro repetições, constituídas por cinco placas de petri contendo 20 sementes cada e quatro caixas gerbox com 25 sementes cada, respectivamente.

Para se determinar o efeito do teor de água na transmissão de $X$. vesicatoria em sementes de tomate, utilizaram-se sementes inoculadas pelo método à vácuo descrito anteriormente (8). Em seguida, diferentes amostras destas sementes foram secas em estufa com circulação forçada de ar, regulada para temperatura de $30 \pm 1{ }^{\circ} \mathrm{C}$, até atingirem $4 \%$ e $8 \%$ de teor de água. Como testemunhas utilizaram-se sementes não inoculadas e inoculadas. Amostras de sementes dos quatro tratamentos foram submetidas a três condições de ambiente antes das avaliações: 1) $90 \%$ de UR e $25^{\circ} \mathrm{C}$ por $48 \mathrm{~h}$; 2 ) sobre papel germitest umedecido (2,5 x o peso do papel por $24 \mathrm{~h}$ ) e 3 ) testemunha. Adotou-se o delineamento inteiramente casualizado com quatro repetições em arranjo fatorial $4 \times 3$.

As avaliações foram realizadas 24 h e 30 dias após a aplicação dos tratamentos de secagem seguindo procedimentos descritos anteriormente. Os teores de água das sementes foram verificados, antes da inoculação, após a inoculação, após a secagem em estufa e após exposição às diferentes condições de ambiente (2). Os dados obtidos nos dois ensaios foram submetidos à análise de variância e teste Scott-Knot a $5 \%$ de probabilidade.

Não houve diferença significativa entre os métodos de inoculação à vácuo e por imersão quanto à porcentagem de sementes infectadas por $X$. vesicatoria avaliado por meio de isolamentos em meio NAM, às 24 horas e 15 dias após a inoculação (Figura $1 \mathrm{~A}$ ). Porém, na recuperação da fitobactéria nas plântulas crescidas em gerbox, a ocorrência maior de $X$. vesicatoria ocorreu nas sementes inoculadas por imersão (Figura 1B). Este fato pode estar relacionado ao maior tempo de exposição da semente com a fitobactéria e do maior teor de água nas sementes, uma vez que a água livre na semente promove um maior desenvolvimento da fitobactéria (5). Observou-se, porém, a partir dos 30 dias uma queda acentuada e, altamente significativa, na incidência de plântulas infectadas e de recuperação de $X$. vesicatoria a partir das sementes (Figura 1A e B). Mesmo sob condições ótimas para infecção, a taxa de transmissão da bactéria das sementes para as plântulas foi baixa, 15 a 17\% (Figura 1A), semelhante ao descrito por Silva (8), embora se tenha constatado nos isolamentos em plântulas a presença da fitobactéria em $43 \%$ e $78 \%$ das sementes inoculadas à vácuo e por imersão, respectivamente (Figura 1B). Estes resultados podem estar associados ao favorecimento da flora microbiana originalmente presentes nas sementes ou que se estabeleceram ao longo dos procedimentos utilizados. O método de inoculação por imersão favoreceu o desenvolvimento de fungos como Penicillium sp. e Aspergillus sp., enquanto que o método de inoculação a vácuo favoreceu o desenvolvimento de Rhizopus sp.. A presença de Pectobacterium sp. nas sementes inoculadas, tanto por imersão quanto a vácuo e semeadas em meio NAM, pode ter contribuído para a redução da incidência de $X$. vesicatoria, ao longo do armazenamento principalmente para as sementes inoculadas por imersão, que apresentaram uma tendência de aumento da ocorrência de Pectobacterium sp (Figura 1C), durante o armazenamento. Em todos os tratamentos, para a avaliação em gerbox, observou-se a presença de Pectobacterium sp. (Figura 1D). Os procedimentos utilizados para inoculação das sementes bem como a fitobactéria, de modo geral, não afetaram a qualidade fisiológica das sementes, medidas pela germinação aos 14 dias, mesmo com o armazenamento das sementes até 45 dias (Figura $1 \mathrm{E})$.

Observou-se o efeito significativo da interação entre os procedimentos de inoculação, secagem e das condições de ambiente antes da montagem dos testes sobre a recuperação e sobrevivência de $X$. vesicatoria e da flora microbiana das sementes de tomate. Observouse uma redução significativa da recuperação de $X$. vesicatoria $\mathrm{em}$ meio NAM a partir das sementes de tomate, quando estas foram submetidas à incubação por $48 \mathrm{hs}$ em ambiente com $90 \%$ de UR e por $24 \mathrm{hs} \mathrm{em}$ papel umedecido, tanto no teste realizado às 24 hs como 30 dias após a aplicação dos tratamentos (Figura 2 A e D). Simultaneamente, observou-se uma elevação no percentual de recuperação de Pectobacterium sp. principalmente quando as sementes foram armazenadas por 30 dias (Figura 2 B e E), e em menor intensidade de bactérias fluorescentes, observada na avaliação realizada logo após a aplicação dos tratamentos, principalmente naquele submetido a $24 \mathrm{~h}$ de incubação em papel umedecido (Figura 2 C). Na avaliação realizada após 30 dias não houve diferenças entre os tratamentos quanto à recuperação de bactérias fluorescentes (Figura 2 F). Embora não se tenham observado diferenças significativas entre os tratamentos de inoculação sem secagem, e aqueles em que as sementes foram secas até $4 \%$ e $8 \%$ de umidade, na avaliação realizada logo após a aplicação dos tratamentos, foi observado efeito benéfico da secagem sobre a sobrevivência da fitobactéria, principalmente até $4 \%$ de umidade (Figuras $2 \mathrm{~A}$ e D). Este resultado pode estar associado à redução da população inicial de Pectobacterium sp. com a secagem até $4 \%$ de umidade, como observado nas avaliações realizadas às 24 horas e 30 dias após a aplicação dos tratamentos, seja no tratamento testemunha como no de incubação por 48 horas sob ambiente com $90 \%$ de UR (Figuras 2 B e E). O efeito benéfico da secagem sobre a sobrevivência de $X$. vesicatoria, porém, foi eliminado durante o processo de embebição das sementes, pois a exposição destas por $24 \mathrm{hs}$ em papel umedecido resultou em redução acentuada na porcentagem de recuperação da fitobactéria e aumento acentuado na recuperação de Pectobacteriun sp., em todos os tratamentos (Figura 2 A, B, D e E).

Os dois métodos de inoculação avaliados foram eficientes e podem ser utilizados em trabalhos de rotina pois não interferem na viabilidade 


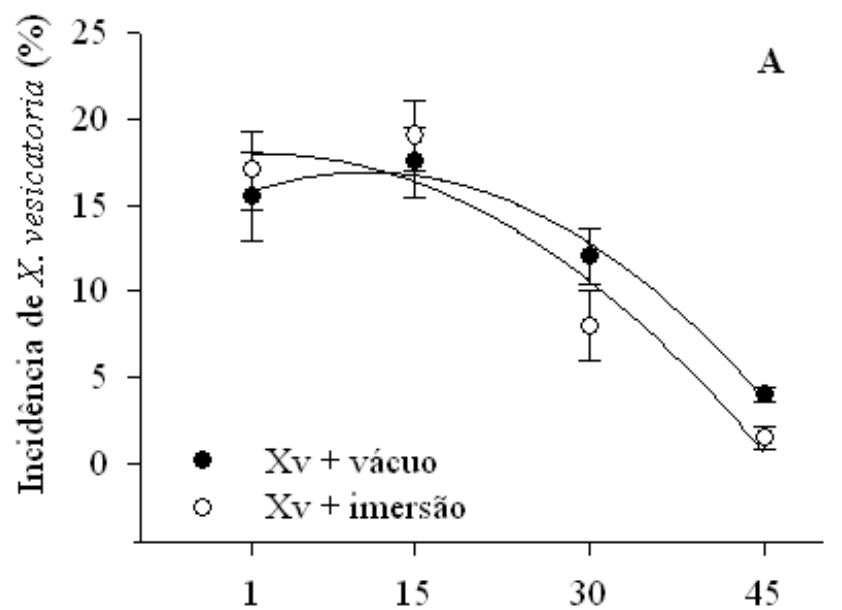

Dias de armazenamento

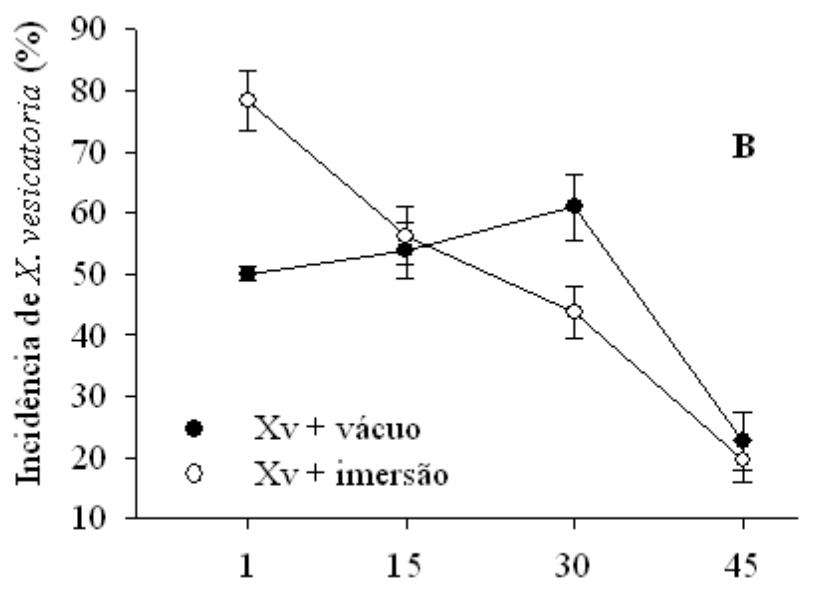

Dias de armazenamento

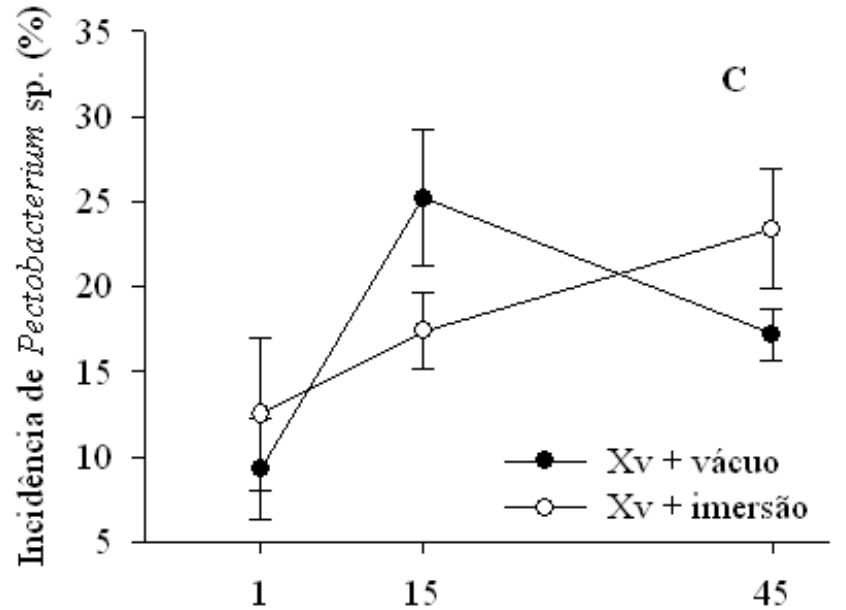

Dias de armazenamento

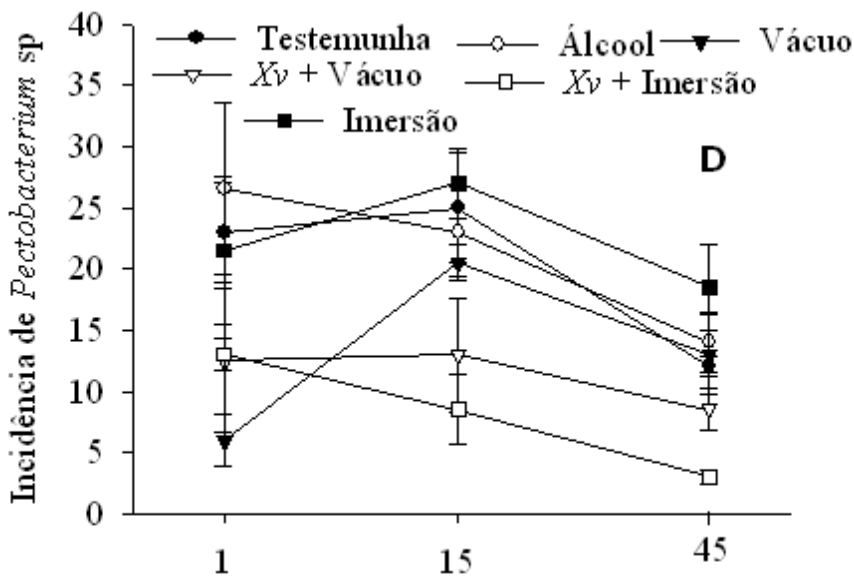

Dias de armazenamento

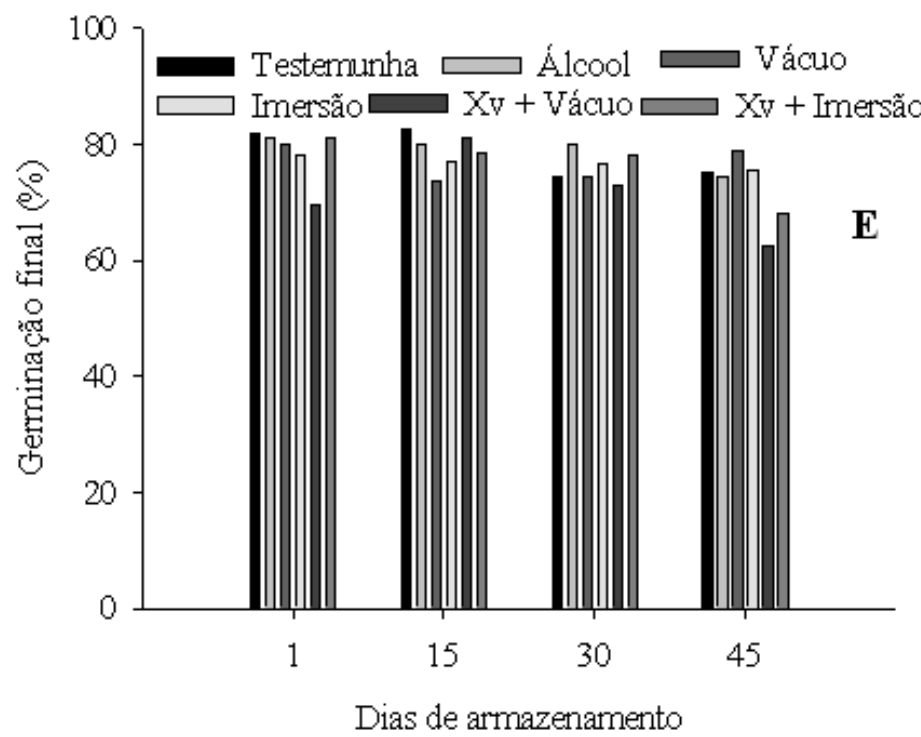

Figura 1 - Eficiência da inoculação de Xanthomonas vesicatoria em sementes de tomate, cv. Miss Brasil, pelos métodos a vácuo e por imersão, expressa pela incidência de plântulas infectadas por Xanthomonas vesicatoria $\left(\mathrm{Y}_{r v+\text { vácuo }}=15,55+0,2468 \mathrm{x}-0,01131 \mathrm{x}^{2}\left(\mathrm{R}^{2}=0,98\right)\right.$ e $\mathrm{Y}_{\mathrm{v}+\mathrm{imerão}}=17,92$ $+0,03331 \mathrm{x}-0,009267 \mathrm{x}^{2}\left(\mathrm{R}^{2}=0,92\right)$ em meio NAM (A); em testes de crescimento em caixas plásticas tipo gerbox (B); Incidência de sementes com Pectobacterium sp. em meio NAM (C); Incidência de plântulas com Pectobacterium sp. em teste de crescimento (D) e percentual de germinação aos 14 dias após semeio em gerbox, durante o período de armazenamento (E). 
24 horas

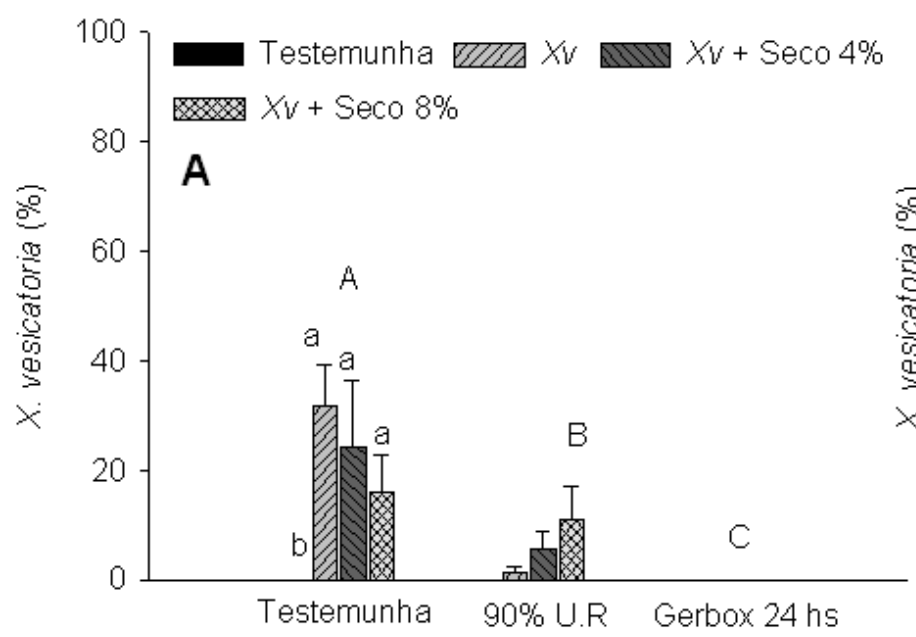

30 dias
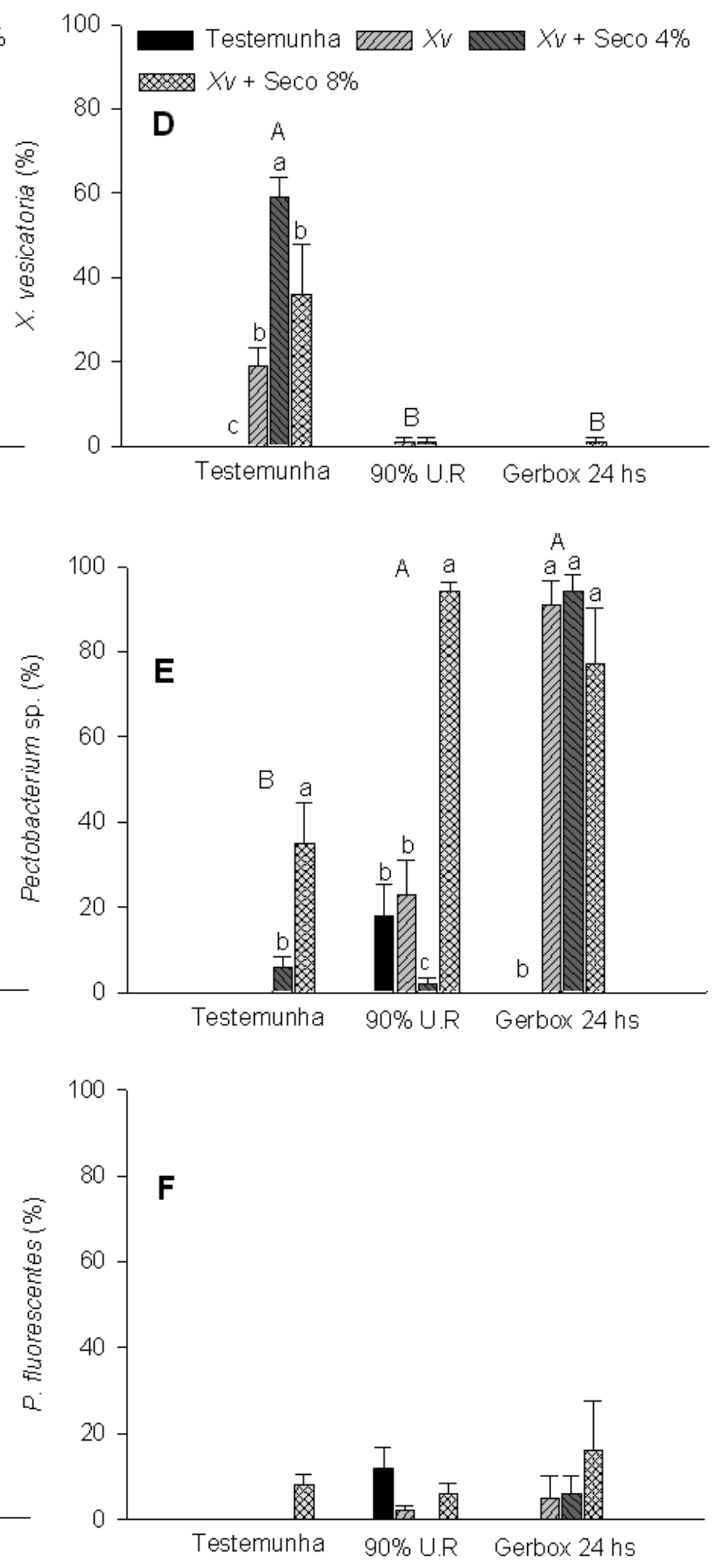

Figura 2 - Efeito da secagem das sementes de tomate inoculadas com Xanthomonas vesicatoria e de tratamentos aplicados às mesmas (testemunha; exposição à ambiente com $90 \%$ U.R. e $30^{\circ} \mathrm{C}$ por 24 horas; embebição em papel germitest por 24 horas) sobre a recuperação da fitobactéria e desenvolvimento da flora microbiana, Pectobaterium sp. e bactérias fluorescentes, após 24 horas (A, B e C) e 30 dias da inoculação (D, E e F). Médias seguidas pela mesma letra maiúscula entre grupos e minúsculas dentro dos grupos, não diferem estatisticamente teste de $\mathrm{Scott}-\mathrm{Knot}(\mathrm{P}<0,05)$. 
e qualidade das sementes. As sementes, porém, devem ser utilizadas até 30 dias após a inoculação, a partir de quando ocorre uma redução acentuada na taxa de recuperação de células viáveis, principalmente no método por imersão. O teor de água das sementes interfere na sobrevivência e na transmissão de $X$ vesicatoria pelas sementes de tomate. Durante o processo de embebição, que ocorre naturalmente na fase inicial da germinação das sementes, ocorre rápida proliferação de bactérias saprófitas, incluindo Pectobacterium sp., que inibem o desenvolvimento de $X$. vesicatoria e podem explicar os baixos percentuais de recuperação e de transmissão da fitobactéria da semente para a plântula nos testes de crescimento em gerbox.

\section{AGRADECIMENTOS}

Ao $\mathrm{CNPq}$ pela concessão da bolsa de Iniciação Científica do primeiro autor e à empresa Agristar pelo fornecimento das sementes de tomate.

\section{REFERÊNCIAS BIBLIOGRÁFICAS}

1. Bashan, Y.; Assouline, I. Complementary bacterial enrichment techniques for the detection of Pseudomonas syringae pv. tomato and Xanthomonas campestris pv. vesicatoria in infested tomato and pepper seeds. Phytoparasitica, v.11, p.187-193, 1983.
2. Brasil. Regras para Análise de Sementes. Ministério da Agricultura e da Reforma Agrária. Brasília, SNDA / DNDV / CLAV, 1992. 365p.

3. Fahy, P.C.; Hayward, A. C. Media and methods for isolation and diagnostic test. In: Fahy, P. C.; Persley, G. J. (Ed.) Plant bacterial diseases: a diagnostic guide. Sydney: Academic Press. 1983. p. 337-338.

4. Galli, J.A.; Panizzi, R.C.; Sader, R.; Camargo, M. Efeito de Xanthomonas campestres pv. vesicatoria na germinação de sementes de couve-flor e eficiência de meios de cultura na detecção do patógeno em sementes de repolho. Revista Brasileira de Sementes, Brasília, v.23, n.2, p. 171-176, 2001.

5. Leben, C. Multiplication of Xanthomonas vesicatoria on tomato seedlings. Phytopathology v. 53, p.778-781, 1963

6. Maringoni, A.C. Detecção de Xanthomonas campestris pv. phaseoli (Smith) Dye em sementes de feijoeiro e conseqüências epidemiológicas. 1993. Tese (Doutorado em Fitopatologia). Escola Superior de Agricultura Luiz de Queiroz. Piracicaba.

7. Oliveira, J. R. de. Detecção de Xanthomonas campestris pv. vesicatoria em sementes de tomateiro. 1995. Tese (Doutorado em Fitopatologia) Universidade Federal de Viçosa. Viçosa

8. Silva, A.M.S. Detecção, erradicação e localização de Xanthomonas campestris pv. vesicatoria em sementes de tomate (Lycopersicon esculentum). 1999 Tese (Mestrado em Fitotecnia). Universidade Federal Rural do Rio de Janeiro. Seropédica.

9.Vauterin, L.; Hoste, B.; Kersters, K.; Swing, J. Reclassification of Xanthomonas. International Journal of Systematic Bacteriology, n.45, p.472-489, 1995. 